\title{
DECOMPOSITION OF TRIPHENYLBISMUTH DICROTONATE IN LIGHT IN THE PRESENCE OF 2-METHYL-2-NITROSOPROPANE
}

\author{
A.V. Gushchin ${ }^{1}$,gushchin@chem.unn.ru \\ O.S. Kalistratova1, olga.kalistratova@yandex.ru \\ A.I. Maleeva ${ }^{1}$, AlevtinaMaleeva@mail.ru \\ V.A. Kuropatov², viach@iomc.ras.ru \\ ${ }_{1}^{1}$ Lobachevsky State University of Nizhni Novgorod, Nizhni Novgorod, Russian Federation \\ ${ }^{2}$ G.A. Razuvaev Institute of Organometallic Chemistry, Russian Academy of Sciences, Nizhni \\ Novgorod, Russian Federation
}

Triphenylbismuth dicrotonate $\mathrm{Ph}_{3} \mathrm{Bi}\left(\mathrm{O}_{2} \mathrm{CCH}=\mathrm{CHCH}_{3}\right)_{2}$ in benzene solution in the presence of 2-methyl-2-nitrosopropane decomposes in light. The phenyl radicals formed as the result of $\mathrm{Ph}_{3} \mathrm{Bi}\left(\mathrm{O}_{2} \mathrm{CCH}=\mathrm{CHCH}_{3}\right)_{2}$ decomposition are confirmed by the spin-trapping method; they can initiate the methylmethacrylate polymerization at room temperature. In the absence of light the decomposition has not been observed.

Keywords: electron paramagnetic resonance, triphenylbismuth dicrotonate, 2-methyl-2nitrosopropane.

\section{Introduction}

Previously, polymethylmethacrylate (PMMA) with addition of various $\mathrm{Bi}(\mathrm{V})$ organometallic compounds was obtained with the use of radical polymerization in the presence of initiators $[1,2]$. It was established that $\mathrm{Bi}(\mathrm{V})$ acrylates accelerated the polymerization reaction. It was suggested that the acceleration was caused by decomposition of organometallic compounds on exposure to diffused light, as the polymerization slowed in the dark. The character of the process was not studied. When various diacyl derivatives of triphenylbismuth were used, no significant change in polymerization rate or molar mass was observed, indicating the predominant role of the $\mathrm{Ph}_{3} \mathrm{Bi}(\mathrm{V})$ fragment. Besides, the previous study of the photo-induced cation polymerization of oxiranes and vinyl monomers was carried out with triaryl(1-pyrenyl)bismuth salts as initiators $[3,4]$. When such compounds were irradiated by visible light, the homolysis of $\mathrm{Bi}-\mathrm{C}$ (pyrene) bond occured with the formation of pyrenyl radical and cation radical of triarylbismuth, which subsequently initiated polymerization. It is also known that organometallic compounds of bismuth(III) can cause the controlled living radical polymerization $[5,6]$.

In this connection it seems interesting to study decomposition of $\mathrm{Bi}(\mathrm{V})$ compounds by the example of triphenylbismuth dicrotonate (TPBDCr) in diffused light by the spin-trapping method, as well as formation of metal-containing PMMA, with the use of this compound in the role of initiator. The structure of TPBDCr and other acyl derivatives of triphenylbismuth has recently been described in the literature $[7,8]$.

\section{Experimental}

Purification of solvents and reagents. Benzene, $\mathrm{Et}_{2} \mathrm{O}$ and THF were dried over anhydrous calcium chloride, then distilled and kept over sodium wire. Chloroform was dried over anhydrous calcium chloride and distilled. Petroleum spirit was used without previous purification. Anhydrous $\mathrm{BiCl}_{3}$ was purified by sublimation $\left(350^{\circ} \mathrm{C}, 0.5\right.$ torr $)$.

Synthesis of $\mathrm{Ph}_{3} \mathrm{Bi}$. Triphenylbismuth was synthesized according to conventional procedure [9] from $\mathrm{BiCl}_{3}$ and $\mathrm{PhMgBr}$ with the use of the benzene and THF (1:2) mixture as the solvent.

Synthesis of $\mathrm{Ph}_{3} \mathrm{Bi}\left(\mathrm{O}_{2} \mathrm{CCH}=\mathrm{CHCH}_{3}\right)_{2}$. The synthesis of triphenylbismuth dicrotonate was carried out according to conventional procedure [10] by the oxidative addition reaction at room temperature in $\mathrm{Et}_{2} \mathrm{O}$ from triphenylbismuth, crotonic acid and tert-butylhydroperoxide (reagent ratio 1:2:1). The product was purified by recrystallization from the medium petroleum spirit - chloroform (4:1). The yield of the purified reaction product equaled $73 \%$, melting point $153{ }^{\circ} \mathrm{C}$. 


\section{Химия элементоорганических соединений}

Synthesis of 2-methyl-2-nitrosopropane (MNP). MNP was synthesized by oxidation of tertbutylamine by $20 \%$ aqueous solution of hydrogen peroxide in the presence of sodium tungstate as a catalyst [11].

Polymerization of MMA in the presence of TPBDCr. Solutions of TPBDCr $(1-5 \% \mathrm{~m} / \mathrm{m})$ were prepared in methylmethacrylate (MMA) without an initiator. The polymerization was carried out in degassed vacuumed ampoules both in diffused light and in the dark at temperature $19-24{ }^{\circ} \mathrm{C}$.

Photodecomposition of TPBDCr in the presence of $M N P$. The solutions for investigation of TPBDCr decomposition in diffused light were prepared as follows: in one elbow of H-ampoule for EPR a sample of MNP $(0.2 \mathrm{~mol} / \mathrm{L})$ was placed, while the other elbow was filled by the benzene solution of TPBDCr. The ampoule was degassed, sealed, and after mixing the EPR spectrum was registered.

EPR spectra were registered on the Bruker ER200D-SRC apparatus with the operating frequency $9.5 \mathrm{GHz}$ in degassed tubes.

\section{Results and Discussion}

We have investigated the decomposition of triphenylbismuth dicrotonate $\mathrm{Ph}_{3} \mathrm{Bi}\left(\mathrm{O}_{2} \mathrm{CCH}=\mathrm{CHCH}_{3}\right)_{2}$ in benzene in the presence of MNP by EPR method. The choice of the solvent is due to its low activity in radical reactions at the chosen conditions. The concentrations of TPBDCr and MNP are $0.2 \mathrm{~mol} / \mathrm{L}$, the reaction has been carried out in light in a sealed and degassed ampoule.

The reaction has resulted in addition compounds of phenyl radicals formed by decomposition of triphenylbismuth dicrotonate, with the spin trap $\mathrm{PhN}(\mathrm{O} \bullet) \mathrm{Bu}-t$, as well as in di-tert-butylnitroxyl radicals $t$ - $\mathrm{BuN}(\mathrm{O} \cdot) \mathrm{Bu}-t$ formed byr decomposition of the spin trap itself, according to the following scheme:

$\mathrm{Ph}_{3} \mathrm{Bi}\left(\mathrm{O}_{2} \mathrm{CCH}=\mathrm{CHCH}_{3}\right)_{2} \rightarrow 2 \mathrm{Ph} \bullet+\mathrm{PhBi}\left(\mathrm{O}_{2} \mathrm{CCHCH}=\mathrm{CHCH}_{3}\right)_{2}$

$$
\begin{aligned}
& \mathrm{Ph} \bullet+t-\mathrm{BuN}=\mathrm{O} \rightarrow \mathrm{PhN}(\mathrm{O} \bullet) \mathrm{Bu}-t \\
& t-\mathrm{BuN}=\mathrm{O} \rightarrow t-\mathrm{Bu} \bullet+\mathrm{NO} \\
& t-\mathrm{Bu} \bullet+t-\mathrm{BuN}=\mathrm{O} \rightarrow t-\mathrm{BuN}(\mathrm{O} \bullet) \mathrm{Bu}-t
\end{aligned}
$$

The EPR spectrum of triphenylbismuth dicrotonate in benzene (with MNP as the spin trap) is shown in Fig. 1.

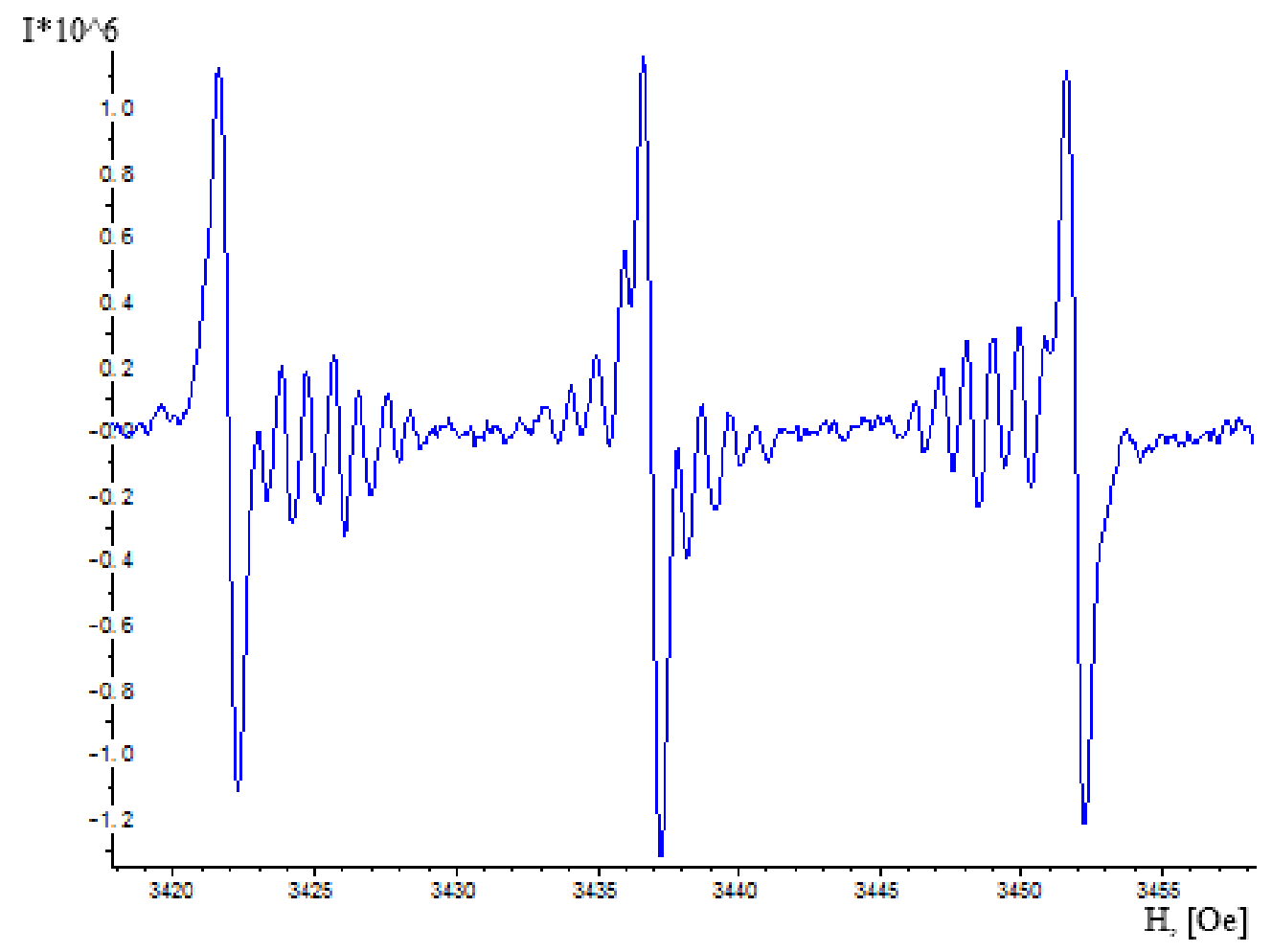

Fig. 1. The EPR spectrum of triphenylbismuth dicrotonate in benzene, the spin trap is MNP 
For the addition compound $\mathrm{PhN}(\mathrm{O} \cdot) \mathrm{Bu}-t$ the values of hyperfine interaction constants have been determined: $\mathrm{a}_{\mathrm{N}}=12.3 \mathrm{Oe}, \mathrm{a}_{\mathrm{H} 1}=1.8 \mathrm{Oe}, \mathrm{a}_{\mathrm{H} 2}=0.85 \mathrm{Oe}, \mathrm{g}=2.0056$, which are in agreement with the literature data for the addition compound generated in benzene by photolysis of $\mathrm{Ph}_{3} \mathrm{Bi}\left(\mathrm{a}_{\mathrm{N}}=12.0 \mathrm{Oe}, \mathrm{a}_{\mathrm{H1}}=1.8 \mathrm{Oe}\right.$, $\left.\mathrm{a}_{\mathrm{H} 2}=1.0 \mathrm{Oe}\right), \mathrm{Ph}_{3} \mathrm{Sb}\left(\mathrm{a}_{\mathrm{N}}=11.9 \mathrm{Oe}, \mathrm{a}_{\mathrm{H} 1}=1.8 \mathrm{Oe}, \mathrm{a}_{\mathrm{H} 2}=0.9 \mathrm{Oe}\right), \mathrm{Ph}_{3} \mathrm{As}\left(\mathrm{a}_{\mathrm{N}}=11.8 \mathrm{Oe}, \mathrm{a}_{\mathrm{H} 1}=1.8 \mathrm{Oe}\right.$, $\mathrm{a}_{\mathrm{H} 2}=0.9 \mathrm{Oe}$ ) [12], as well as with the data obtained for other sources of phenyl radical in benzene $\left(\mathrm{a}_{\mathrm{N}}=12.3 \mathrm{Oe}, \mathrm{a}_{\mathrm{H} 1}=2.0 \mathrm{Oe}, \mathrm{a}_{\mathrm{H} 2}=0.9 \mathrm{Oe}\right)[13]$. For the addition compound $t-\mathrm{BuN}(\mathrm{O} \bullet) \mathrm{Bu}-t$ the values $\mathrm{a}_{\mathrm{N}}=15.4 \mathrm{Oe}, \mathrm{g}=2.0061$, which are also in agreement with the literature data for the corresponding addition compound generated in benzene by decomposition of $\alpha$-isopropylazide $\left(a_{N}=15.4\right.$ Oe, $\mathrm{g}=2.0061)$ [14] and by photolysis of 2-methyl-2-nitrosopropane $\left(\mathrm{a}_{\mathrm{N}}=15.4 \mathrm{Oe}, \mathrm{g}=2.0057\right)$ [15].

Formation of phenyl radicals can also be confirmed by thermodynamic and X-ray diffraction data. It is known that the dissociation energy of the $\mathrm{Bi}-\mathrm{C}(\mathrm{Ph})$ bond equals $46.2 \mathrm{kcal} / \mathrm{mol}$ for triphenylbismuth [16], while the dissociation energy of the $\mathrm{Bi}-\mathrm{O}$ bond equals $80.6 \mathrm{kcal} / \mathrm{mol}$ for bismuth monoxide [17]. The X-ray diffraction analysis points at the bidentate character of acyl ligands binding with a bismuth atom; though the bond length of $\mathrm{Bi}-\mathrm{O}$ is somewhat greater, the breaking occurs to the $\mathrm{Bi}-\mathrm{C}$ bonds [5].

The fact of free radical formation was used by us to obtain PMMA. The polymerization of MMA, with various content of dissolved TPBDCr as an initiator, was carried out in diffused light at room temperature. Formation of the solid block was observed in less than $20 \mathrm{~h}$. After storage of the ampoule for 30 days the obtained samples were yellow and opaque, practically insoluble in organic solvents, which indicated additional linking of macromolecules. Low solubility significantly hampered the subsequent analysis of such polymers. It is necessary to emphasize that storage of TPBDCr in methymethacrylate at similar conditions, but in the absence of light, did not lead to polymerization. Solidification of the solution was not observed even in 2 weeks. At present the study is on for production of transparent polymer samples, containing triphenylbismuth diacylates, at similar conditions.

\section{Conclusions}

1. Decomposition of triphenylbismuth dicrotonate in diffused light in benzene solution in the presence of 2-methyl-2-nitrosopropane leads to formation of phenyl radicals that are registered in the form of the addition compound $\mathrm{PhN}(\mathrm{O} \cdot) \mathrm{Bu}-t$.

2. Polymerization of methylmethacrylate with addition of triphenylbismuth dicrotonate $(1-5 \% \mathrm{~m} / \mathrm{m})$ as a radical initiator is carried out in diffused light at room temperature with formation of yellow-colored opaque polymethylmethacrylate blocks that are insoluble in organic solvents. In the absence of light the polymerization does not occur. mol_a).

The research was supported by the Russian Foundation for Basic Research (Agreement No. 14-03-31625

\section{References}

1. Dodonov V.A., Gushchin A.V., Kuznetsova J.L., Morugova V.A. [Triphenylbismuth and Triphenylantimony Diacrylates in the Synthesis of Metal-containing Polymethylmethacrylate]. Vestnik of Lobachevsky State University of Nizhni Novgorod. Ser. Chemistry, 2004, vol. 1, no. 4, pp. 86-94. (in Russ.)

2. Gushchin A.V., Shashkin D.V., Shcherbakova T.S., Somov N.V., Baranov E.V., Fukin G.K., Shavyrin A.S., Rykalin V.I., Dodonov V.A. [Synthesis and Structure of Tetraphenylantimony Acrylate and its Insertion into Polymethylmethacrylate]. Vestnik of Lobachevsky State University of Nizhni Novgorod. Ser. Chemistry, 2010, vol. 6, pp. 68-72. (in Russ.)

3. Matano Y., Shinokura T., Yoshikava O., Imahori H. Triaryl(1-pyrenyl)bismuthonium Salts: Efficient Photoinitiators for Cationic Polymerization of Oxiranes and a Vinyl Ether. Org. Lett., 2008, vol. 10, no. 11, pp. 2167-2170. DOI: 10.1021/ol8005453.

4. Matano Y. Pentavalent Organobismuth Reagents in Organic Synthesis: Alkylation, Alcohol Oxidation and Cationic Photopolymerization. Top. Curr. Chem., 2012, vol. 311, pp. 19-44. DOI: 10.1007/128_2011_167. 
5. Yamago S. Development of Organotellurium-Mediated and Organostibine-Mediated Living Radical Polymerization Reactions. J. Polym. Sci. Part A: Polym. Chem., 2006, vol. 44, pp. 1-12. DOI: 10.1002/pola.21154.

6. Yamago S. Precision Polymer Synthesis by Degenerative Transfer Controlled/Living Radical Polymerization Using Organotellurium, Organostibine, and Organobismuthine Chain-Transfer Agents. Chem. Rev., 2009, vol. 109, no. 11, pp. 5051-5068. DOI: 10.1021/cr9001269.

7. Andreev P.V., Somov N.V., Kalistratova O.S., Gushchin A.V., Chuprunov E.V. Bis(but-2enoato- $\kappa O$ )triphenylbismuth(V). Acta Crystal. Section E, 2013, vol. 69, no. 6, pp. m333. DOI: $10.1107 / \mathrm{S} 1600536813013317$.

8. Sharutin V.V., Egorova I.V., Sharutina O.K. [Synthesis and Structure of Aryl Bismuth Compounds]. Butlerov Communications, 2004, vol. 5, no. 1, pp. 16-25.

9. Kocheshkov K.A., Skoldinov A.P., Zemlyanskii N.N. Metody elementoorganicheskoi khimii. Sur'ma, vismut [Methods of Organometallic Chemistry. Antimony, Bismuth]. Moscow, Nauka Publ., 1976. $483 \mathrm{p}$.

10. Suzuki H. Organobismuth chemistry. Amsterdam-London-New York-Oxford-Paris-ShannonTokyo, Elsevier, 2001. 619 p.

11. Smith R.J., Ragni R.M. Reaction of Di-tert-butylnitroxide with Methyl Trifluoromethanesulfonate. Unexpected Formation of N-tert-butylhydroxylamine Radical Cation in Trifluoromethanesulfonic acid. J. Org. Chem., 1981, vol. 46, no. 21, pp. 4307-4309. DOI: 10.1021/jo00334a048.

12. Xu G., Zhou J., Tang Y. Application of Spin Trapping Technique in Photolysis of Compounds $\mathrm{Ph}_{3} \mathrm{M}(\mathrm{M}=\mathrm{N}, \mathrm{P}$, As, S b, Bi). Wuli Huaxue Xuebao, 1985, vol. 1, no. 1, pp. 6-11. DOI: 10.3866/PKU.WHXB19850102.

13. Zubarev V.E., Belevsky V.N., Bugaenko L.T. [Use of Spin Traps to Study the Mechanism of Radical Processes]. Russian Chemical Reviews, 1979, vol. XLVIII, no. 8, pp. 1361-1392. DOI: 10.1070/RC1979v048n08ABEH002407. (in Russ.)

14. Cook M.D., Ng L.L., Roberts B.P. Spin-trapping of Alpha-azidoalkyl Radicals. Tetrahedron Lett., 1983, no. 24, pp. 3761-3764. DOI: 10.1016/S0040-4039(00)94528-3.

15. Joshi A., Yang G. Spin Trapping of Radicals Generated in the UV Photolysis of Alkyl Disulfides. J. Org. Chem., 1981, vol. 46, no. 18, pp. 3736-3738. DOI: 10.1021/jo00331a035.

16. Freedman L.D., Doak G.O. Preparation, Reactions, and Physical Properties of Organobismuth Compounds. Chem. Rev., 1982, vol. 82, pp. 15-57. DOI: 10.1021/cr00047a002.

17. Luo Y. Comprehensive Handbook of Chemical Bond Energies. CRS Press, 2007. 1687 p.

Received 12 November 2015

удк $547.1 ' 13+547.024$

DOI: $10.14529 /$ chem160108

\title{
РАСПАД ДИКРОТОНАТА ТРИФЕНИЛВИСМУТА НА СВЕТУ В ПРИСУТСТВИИ 2-МЕТИЛ-2-НИТРОЗОПРОПАНА
}

\author{
А.В. Гущин', О.С. Калистратова ${ }^{1}$, А.И. Малеева', В.А. Куропатов ${ }^{2}$ \\ ${ }^{1}$ Нижегородский государственный университет им. Н.И. Лобачевского, \\ 2. Нижний Новгород \\ ${ }^{2}$ Институт металлоорганической химии РАН им. Г.А. Разуваева, г. Нижний Новгород
}

Дикротонат трифенилвисмута $\mathrm{Ph}_{3} \mathrm{Bi}\left(\mathrm{O}_{2} \mathrm{CCH}=\mathrm{CHCH}_{3}\right)_{2}$ в присутствии 2-метил-2нитрозопропана на свету распадается в бензоле. Образующиеся в результате распада $\mathrm{Ph}_{3} \mathrm{Bi}\left(\mathrm{O}_{2} \mathrm{CCH}=\mathrm{CHCH}_{3}\right)_{2}$ фенильные радикалы подтверждены методом спиновых 
ловушек и способны инициировать полимеризацию метилметакрилата при комнатной температуре. В отсутствие света распада не наблюдается.

Ключевые слова: ЭПР, дикротонат трифенилвисмута, 2-метил-2-нитрозопропан.

\section{Литература}

1. Диакрилаты трифенилвисмута и трифенилсурьмы в синтезе металлсодержащего полиметилметакрилата / В.А. Додонов, А.В. Гущин, Ю.Л. Кузнецова и др. // Вестник Нижегородского университета им. Н.И. Лобачевского. Сер. «Химия». - 2004. - Т. 1, № 4. C. $86-94$.

2. Синтез и строение акрилата тетрафенилсурьмы и введение его в полиметилметакрилат / А.В. Гущин, Д.В. Шашкин, Т.С. Щербакова и др. // Вестник Нижегородского университета им. Н.И. Лобачевского. Сер. «Химия». - 2010. - Т. 6. - С. 68-72.

3. Triaryl(1-pyrenyl)bismuthonium Salts: Efficient Photoinitiators for Cationic Polymerization of Oxiranes and a Vinyl Ether / Y. Matano, T. Shinokura, O. Yoshikava et al. // Org. Lett. - 2008. - V. 10, № 11. - P. 2167-2170.

4. Matano, Y. Pentavalent Organobismuth Reagents in Organic Synthesis: Alkylation, Alcohol Oxidation and Cationic Photopolymerization / Y. Matano // Top. Curr. Chem. - 2012. V. 311. - P. 19-44.

5. Yamago, S. Development of Organotellurium-Mediated and Organostibine-Mediated Living Radical Polymerization Reactions / S. Yamago // J. Polym. Sci. Part A: Polym. Chem. - 2006. - V. 44. P. 1-12.

6. Yamago, S. Precision Polymer Synthesis by Degenerative Transfer Controlled/Living Radical Polymerization Using Organotellurium, Organostibine, and Organobismuthine Chain-Transfer Agents / S. Yamago // Chem. Rev. - 2009. - V. 109, № 11. - P. 5051-5068.

7. Bis(but-2-enoato- $\kappa O$ )triphenylbismuth(V)/ P.V. Andreev, N.V. Somov, O.S. Kalistratova et al. // Acta Crystal. Section E. - 2013. - V. 69, № 6. - P. m333.

8. Шарутин, В.В. Синтез и строение арильных соединений висмута / В.В. Шарутин, И.В. Егорова, О.К. Шарутина // Бутлеровские сообщения. - 2004. - Т. 5, № 1. - С. 16-25.

9. Кочешков, К.А. Методы элементоорганической химии. Сурьма, висмут / К.А. Кочешков, А.П. Сколдинов, Н.Н. Землянский. - М.: Наука, 1976. -483 с.

10. Suzuki, H. Organobismuth Chemistry / H. Suzuki. - Amsterdam-London-New York-OxfordParis-Shannon-Tokyo, Elsevier, 2001.-619 p.

11. Smith, R.J. Reaction of Di-tert-butylnitroxide with Methyl Trifluoromethanesulfonate. Unexpected Formation of N-Tert-butylhydroxylamine Radical Cation in Trifluoromethanesulfonic Acid / R.J. Smith, R.M. Ragni // J. Org. Chem. - 1981. - V. 46, № 21. - P. 4307-4309. DOI: 10.1021/jo00334a048.

12. Xu, G. Application of Spin Trapping Technique in Photolysis of Compounds $\mathrm{Ph}_{3} \mathrm{M}(\mathrm{M}=\mathrm{N}, \mathrm{P}$, As, Sb, Bi) / G. Xu, J. Zhou, Y. Tang // Wuli Huaxue Xuebao. - 1985. - V. 1, № 1. - P. 6-11. DOI: 10.3866/PKU.WHXB19850102.

13. Зубарев, В.Е. Применение спиновых ловушек для исследования механизма радикальных процессов / В.Е. Зубарев, В.Н. Белевский, Л.Т. Бугаенко // Успехи химии. - 1979. - T. XLVIII. № 8. - C. 1361-1392. DOI: 10.1070/RC1979v048n08ABEH002407.

14. Cook, M.D. Spin-trapping of Alpha-azidoalkyl Radicals / M.D. Cook, L.L. Ng, B.P. Roberts // Tetrahedron Lett. - 1983. - №. 24. - P. 3761-3764. DOI:10.1016/S0040-4039(00)94528-3.

15. Joshi, A. Spin Trapping of Radicals Generated in the UV Photolysis of Alkyl Disulfides / A. Joshi, G. Yang // J. Org. Chem. - 1981. - V. 46, № 18. - P. 3736-3738. DOI:10.1021/jo00331a035.

16. Freedman, L.D. Preparation, Reactions, and Physical Properties of Organobismuth Compounds / L.D. Freedman, G.O. Doak // Chem. Rev. - 1982. - V. 82. - P. 15-57.

17. Luo, Y. Comprehensive handbook of chemical bond energies / Y. Luo. - CRS Press, 2007. $1687 \mathrm{p}$. 


\section{Химия элементоорганических соединений}

Гущин Алексей Владимирович - доктор химических наук, профессор, декан химического факультета, Нижегородский государственный университет им. Н.И. Лобачевского. 603950, г. Н. Новгород, пр. Гагарина, 23. E-mail: gushchin@chem.unn.ru

Калистратова Ольга Сергеевна - аспирант химического факультета, Нижегородский государственный университет им. Н.И. Лобачевского. 603950, г. Н. Новгород, пр. Гагарина, 23. E-mail: olga.kalistratova@yandex.ru

Малеева Алевтина Игоревна - аспирант химического факультета, Нижегородский государственный университет им. Н.И. Лобачевского. 603950, г. Н. Новгород, пр. Гагарина, 23. E-mail: Alevtinamaleeva@mail.ru

Куропатов Вячеслав Александрович - кандидат химических наук, старший научный сотрудник, Институт металлоорганической химии РАН им. Г.А. Разуваева. 603137, г. Нижний Новгород, ул. Тропинина, 49. E-mail: viach@iomc.ras.ru

Поступила в редакцию 12 ноября 20152.

\section{ОБРАЗЕЦ ЦИТИРОВАНИЯ}

Decomposition of triphenylbismuth dicrotonate in light in the presence of 2-methyl-2-nitrosopropane / A.V. Gushchin, O.S. Kalistratova, A.I. Maleeva, V.A. Kuropatov // Вестник ЮУрГУ. Серия «Химия». - 2016. T. 8, № 1. - C. 51-56. DOI: 10.14529/chem 160108

\section{FOR CITATION}

Gushchin A.V., Kalistratova O.S., Maleeva A.I., Kuropatov V.A. Decomposition of Triphenylbismuth Dicrotonate in Light in the Presence of 2-Methyl-2nitrosopropane. Bulletin of the South Ural State University. Ser. Chemistry. 2016, vol. 8, no. 1, pp. 51-56. DOI: $10.14529 /$ chem 160108 